различным причинам. Например, одной из причин является тот факт, что многие метафоры стали «мертвыми», и сейчас мы уже не можем определить их происхождение. Ещё одна, более банальная причина заключается в том, что мы просто «не видим, что происходит» [по Лакоффу].

$$
* * *
$$

1. Верещагин Е. М., Костомаров В. Г. Язык и культура. - М.: 2000. - 120 с.

2. Габуниа 3.М., Улимбашева Э.Ю. Межкультурная коммуникация как миросозидающий факт языка: учеб. пособие по спецкурсу «Межкультурная коммуникация». - Нальчик, 2005. - 176 с.

3. Головлева Е.П. Основы межкультурной коммуникации/ Е.П. Головлева //М.: Феникс, 2008.

4. Научная библиотека диссертаций и авторефератов disserCat http://www.dissercat.com/content/mezhkulturnayakommunikatsiya-v-sisteme-sotsiologicheskogo-znaniya\#ixzz5W7prDoHm

5. Гришаева Л.И! Введение в теорию, межкультурной коммуникации- /Л.И. Гришаева. Воронеж : Воронеж, гос. ун-т, 2003: - 386 с.

6. Дэцзидэма Д., Будаева С. В. Язык как средство трансляции культуры в процессе межкультурной коммуникации // Гуманизация образования. - 2014. - № 6. - С. 51-55.

\title{
Алимханова М.X. \\ Фразеологические единицы с антропонимом на немецком языке \\ ФГБОУ ВО «Чеченский государственный университет им. А.А. Кадырова»
}

(Россия, Грозньй)

doi: 10.18411/trnio-12-2021-211

\section{Аннотация}

Данная статья посвящена изучению фразеологизмов с одним компонентом антропонимом в современном немецком языке. В немецком языке объем фразеологизмов с названиями невелик, но такие фразеологизмы все же привлекают внимание исследователей. Ассоциации, связанные с конкретным личным именем, определяют семантику фразеологизма, к которому оно принадлежит.

Ключевые слова: фразеология, антропонимы, онимы, единства, фольклор.

\section{Abstract}

This article is devoted to the study of phraseological units with an anthroponym component in the modern German language. In German, the volume of phraseological units with names is small, nevertheless, such phraseological units attract the attention of researchers. Associations that are associated with a particular personal name predetermine the semantics of the phraseology that it is part of.

Keywords: phraseology, anthroponyms, onyms, unity, folklor.

Фразеология - это раздел языкознания, в котором изучаются лексически устойчивые словосочетания, которые называются фразеологизмами или фразеологическими оборотами. Понятие фразеология восходит к греческому $\Phi \mathrm{PA} \Sigma \mathrm{E} \Omega$, что в свою очередь можно перевести как “говорю”, “сообщаю”. Швейцарский ученый Чарльз Балли считается основоположником фразеологии как самостоятельной дисциплины «Traite de stylistique francaise», которая вышла в свет в 1909 году. Однако, фразеология получила более детальное рассмотрение только в начале 40-х годов XX века в трудах советского лингвиста и литературоведа В. В. Виноградова (1977). Именно В. В. Виноградов впервые широко установил понятие фразеологии, дал первую классификацию и определил основные направления изучения фразеологии. После этого аналогичный опыт имел место в Европе, особенно в Германии, где влияние советской фразеологии было очень велико.

Частота использования личных имен как элементов фразеологических единиц зависит от языка: в болгарском языке, к примеру, они встречается чаще, чем в русском. В немецком языке объем фразеологизмов с именами невелик, тем не менее, такие фразеологизмы привлекают внимание исследователей [11, с. 58]. Суть таких фразеологизмов достаточно объяснима, так как здесь обнаруживается связь между фразеологизмом и тем или иным 
носителем имени. Иногда эта связь ослабевает, что носители имени уходят в забытье и их суть может быть раскрыта небольшому кругу исследователей.

Антропонимика - это раздел ономастики, изучающий антропонимы - правильное наименование людей: личные имена, отчества, фамилии, прозвища или псевдонимы. Ассоциации, связанные с конкретным личным именем, определяют семантику фразеологизма, к которому оно принадлежит [6, с. 48].

К таким именам мы относим мужские и женские антропонимы: Johannes (Hans), Friedrich (Fritz), Heinrich (Heine, Hinz), Wilhelm, Konrad (Kunz), Peter, Michel, Otto, Maximillian (Max), а также женские антропонимы: Margarethe (Grete), Liese, Marie, Wilhelmine (Minna).

Среди различных классов онимов чаще всего в немецком языке используются имена собственные, при этом чаще имена людей, чем их фамилии. Отметим, что современные имена во фразеологизмах не встречаются.

Frech wie Oskar - разг. нахал из нахалов. Мальцева [6, с. 35] приводит несколько вариантов происхождения данного фразеологизма:

Oskar Saifert был торговцем, который был известен своей наглостью.

Oskar Blümental - писатель, есть мнение, что фразеологизмы имеет отношение к нему.

Du kannst es machen (halten) wie Pastor Asmann - разг. делай как хочешь. Выражение либо восходит к имени гессенского пастора Рассмана, который, согласно легенде, действовал по принципу «Я делаю то, что считаю правильным». По другому мнению, выражение относится к имени тюрингского пастора Ассманна, который, сопровождая герцога Августа на охоте, убил зайца Библией. Герцог ответил ему, что он может делать с зайцем все, что хочет, так как заяц был убит Библией. погибнуть.

Robert Blum - (букв. быть расстрелянным как Роберт Блюм) - разг. нелепо

О фразеологических единицах мы можем найти высказывания Блюма, который был публицистом политиком в 19 веке, и попал под жирного в немецкой революции. В 1848 году он был членом Саксонской демократической партии, и некоторое время возглавлял ее. Однако в последствии он был арестован и по приказу Австрийского военного суда приговорен к смертной казни. Но зато в ходе судебного разбирательства он не отказался от своей идеологии.

С именем великого немецкого писателя Ф. Шиллера связано несколько фразеологизмов, например:

So was lebt und Schiller тиsste sterben! -букв. такой вот дурак живет, а Шиллер умер! Данный фразеологизм носит шутливый окрас.

В словаре Д.Г Мальцевой (2002) приводится целый ряд фразеологизмов, в составе которых содержится имя Hans:

Hans Allerlei-разг. торговец мелочными товарами;

Hans Huckebein - несчастный человек;

Großer Hans - пудинг;

Die großen Hansen - важные особы;

Der blanke Hans (blanker Hans) - Северное море во время шторма, букв. свинцовыи й Ганс. Основанием для такого обозначения служит тот факт, что вода в северном море в непогоду перед штормом приобретает металлический оттенок (blank - блестящий, сверкающий).

Hanswurst - дурак. Гансвурст - комический персонаж немецкого народного театра.

С именем Гансвурста связано еще одно фразеологическое выражение - den Hanswurst spielen (machen) - cтроить из себя дурака; дурачиться. Интересно то, что уменьшительноласкательная форма данного имени (Hänschen) употребляется в значении "ребенок", “молодой”.

Jeder Hans findet seine Grete - “каждый мужчина когда-нибудь найдет себе жену по вкусу” (букв. каждый Ганс находит свою Грету).

Личное имя Heinrich встречается в ряде фразеологизмов:

Der sanfte Heinrich - сладкий ликер особого сорта в средней и верхней Германии; 
Langer Heinrich - отмьчка;

Blauer Heinrich - перловая каша; суп для бедняков; жидкий, водянистый суп;

Den müden Heinrich spielen - вешать нос; падать духом;

Roter Heinrich - дикий щзвель;

Süßer Heinrich - сахарнииа;

Stolzer Heinrich - рисовая каша.

Часто встречающимся является и личное имя Otto. Имя перешло в нарицательное, и мы его можем встретить в целом ряде фразеологических единиц, зафиксированных в словаре Г. Кюппера (1970):

Schräger Otto - подозрительный человек;

Den Otto machen - притворяться обиженным.

Имя Marie в разговорной речи также используется для обозначения денег, например Dicke Marie (толстая Мари) - крупная сумма денег. Эта фразеологическая единица употреблялась в солдатском жаргоне, но постепенно перешла в обиходный язык.

Итак, мы пришли к следующим выводам, что во фразеологизмах немецкого языка чаще всего используется:

- в основном старые, народные, когда-то широко распространенные мужские имена, женские имена встречаются реже;

фразеологические единицы, в которых имя собственное связано с бытом, литературой и фольклором;

- библейские и мифологические имена.

$$
* * *
$$

1. Баранов А.Н. / Добровольский Д.О. Аспекты теории фразеологии. - М.: Знак, 2008. -656 c.

2. Бинович Л.Э / Гришин Н.Н. Немецко-русский фразеологический словарь. М: “Русский Язык”, 1975 - 656 с.

3. Емельянова Е.В. Анализ фразеологических универсалий немецкого языка. Вестник РУДН, серия "Вопросы образования: языки и специальность”, 2010, №4 - 14 с. (61- 74)

4. Комарова Р.А. Немецкая антропонимика. Учеб. пособие по спец. курсу. для филол. факультетов. Саратов, 1979 - $37 \mathrm{c}$.

5. Мальцева Д.Г. Страноведение через фразеологизмы. Москва: Высшая школа, 1991. - 173 с

6. Мальцева Д.Г. Немецко-русский фразеологический словарь с лингвострановедческим комментарием - М.: «Азбуковник», «Русские Словари», 2002. - 350 с.

7. Виноградов В.В. Избранные труды. Лексикология и лексикография. М: издательство “Наука", 1977 - $312 \mathrm{c}$.

8. Полчанинова Е.О. Афоризм во фразеологии и фразеологизм в афористике современного немецкого языка (лингвокультурологический аспект) // Автореферат диссертации на соискание учёной степени кандидата филологических наук. Москва, $2012-22$ с.

9. $\quad$ Küpper H. Wörterbuch der deutschen Umgangssprache. Jugenddeutsch von A bis Z. Düsseldorf/Hamburg: Claassen Verlag, $1970-438 \mathrm{~S}$.

10. Fleischer, W. Zur pragmatischen Potenz der Phraseologismen // Linguistische Studien; Reihe A, H. 80. Berlin, 1981. - S.76-88.

11. Fleischer, W. Phraseologie der deutschen Gegenwartssprache. Leipzig: Bibliographisches Institut Leipzig, 1982. $250 \mathrm{~S}$.

\section{Амыкова В.Н., Очиров Б.В., Хайчеева Б.А., Эренженова Б.Н. Научно-методическая деятельность в учреждении среднего профессионального образования как фактор совершенствования профессиональной компетентности преподавателей}

ФГБОУ ВО «Калмыцкий государственный университет имени Б.Б.Городовикова» (Россия, Элиста)

doi: 10.18411/trnio-12-2021-212

Аннотация

Вопросы, связанные с формированием, развитием и совершенствованием профессиональной компетентности современного преподавателя, весьма насущны и актуальны. Наиболее интересным представляется рассмотрение данного процесса через призму научно-методической работы, поскольку, с точки зрения практики, именно этот вид 